\title{
Organochlorine Pesticide Levels in Barn Owls Collected
}

\section{n León, Spain}

N.at:'de Sierra' and Diego Santiago ${ }^{2}$

'Department of Biochemistry and Molecular Biology, Biology, Physiology and Deparmacology, Faculty of Veterinary, The University of Leon, Leon, Spain and charmacology, Farmacology and Toxicology. Faculty of Veterinary, The

University of Cordoba, Cordoba, Spain

(hesticides Several studies have demostalion of several bird have been the cause of the decline in population of several organochlorine pesticides due to its trophic position. As it is indicated by Joiris et al.. 1977, the study of the contamination f birds of prey by persistent pollutants, such as organochlorine o. birds or prey by persiste use of these substances and their resicues, reflects both the concentration along the food chains. used as a measure of the contamination of the, ecosystems by persistent pesticides, and because of that reason they are frequently included in monitoring programs in spite of their reduced populations.

me purpose of the present study is to give some data on the arels of organochlorine pesticides in organs and tissues of barn cerels of nils (Tyto alba, scop.) collet North-West of Spain. Barn owl is a nally feebly flying birds, is pimarily small rodents, occasionally feebly flying birds, mostly inmatures, and insects. This bird is resident in the named province of Leon, therefore, a study of organochlorine pesticide evels will give us a degree of contamination in the area by this rersistent pollutants.

MATERIALS AND METHODS

organochlorine pesticide residues were determined in 23 barn owls obtained in Leon, Spain. They were measured in muscle, liver, fat, brain and kidney, by using a total of 91 samples.

The whole of the brain was removed for insecticide analysis. , ortiors of about 4 grams were taken from kidney, muscle and liver samples. It was only possible to obtain the perivisceral fat in in indiduals, and its weight was variable depending on the birc in $f$ to samples were frozen after collection int il anatutical treatment was performed.

cone ronrint requests to Matilde Sierra at the above address. 


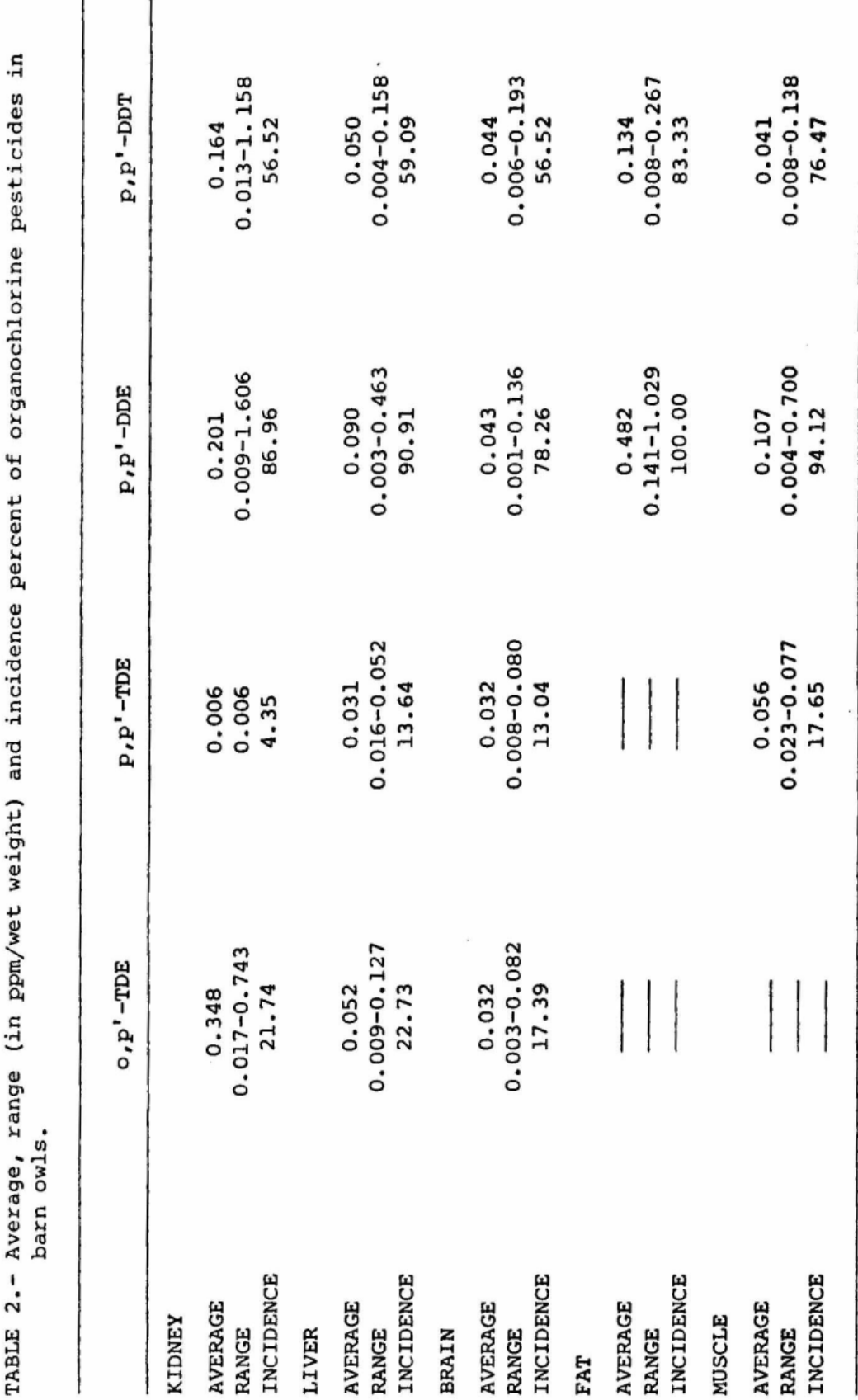

The analytical treatment basicaly consists in the homogenization of each sample (Ahmad, 1979), extraction of homogenates and clean-up according to the method provided by Richardson et al. 1971. All extracts were eluted through an activated florisil

column to separate the pesticides in two fractions. The florisil column was conditioned for $24 \mathrm{~h}$ at $130^{\circ} \mathrm{C}$.

cleaned-up hexane extracts of tissues were examined qualitatively and quantitatively by gas-chromatography using a Hewlett Packard gas-chromatograph fitted with a nickel 63 electron capture detector.

The samples were analyzed on two gas chromatographic columns 6 feet long and $1 / 4$ inch inside diameter, containing (a) a 1.58 coating of OV-17/1.958 of OF-1 on 100-200 mesh chromsorb W (AW/ DMCS) and (b) 3.88 of SE-30 on 80-100 mesh chromsorb W (AW/DMCS).

The operating temperatures were: inlet $250^{\circ} \mathrm{C}$; detector $300^{\circ} \mathrm{C}$; column (a) $200^{\circ} \mathrm{C}$ and column (b) $180^{\circ} \mathrm{C}$. The carrier gas was 58 argon-methane at a flow rate of $25 \mathrm{ml} / \mathrm{min}$.

Extracts were analyzed for $\alpha-\mathrm{HCH}$, lindane, heptachlor epoxide, aldrin, dieldrin, endrin, $0, p^{\prime}-T D E, p, p^{\prime}-T D E, p, p^{\prime}-D D E$ and $\mathrm{p}, \mathrm{p}^{\prime}-\mathrm{DDT}$ and were quantified by using a standard.

\section{RESULTS AND DISCUSSION}

The mean residue levels and ranges of organochlorine pesticides are summarized in Table 1 and Table 2, expressed in parts per million (ppm) by weight of wet sample. In the same tables is also summarized the incidence percent of organochlorine pesticides in the five types of samples.

$\alpha-\mathrm{HCH}$ was found in most analyzed liver, kidney, brain and muscle samples. In a previous paper (Sierra et al., 1984) we have obtained similar results in buzzards (Buteo buteo, L.).

The highest mean residue level of $\alpha-\mathrm{HCH}$ was found in fat, 1.073 ppm, and this also represented the highest mean concentration for any organochlorine pesticide detected in this species.

D.P'-DDE was detected in all the fat samples, and its mean concentration was 0.482 , the highest for this pesticide.

The residual levels that have been detected are lower than those reported by other authors. Peakall and Kemp, 1980, report a $\mathrm{p}, \mathrm{p}^{\prime}-\mathrm{DDE}$ concentration of $0.05 \mathrm{ppm}$ in muscle of barn owls collected in Canada. The average we have found in similar samples, $0.107 \mathrm{ppm}$, is higher than this one; nevertheless, these authors reported at the same time in Pretoria a $3.22 \mathrm{ppm}$ and $0.8 \mathrm{ppm}$ of $\mathrm{p}, \mathrm{p}^{\prime}-\mathrm{DDE}$ in muscle and brain respectively, which are 30 and 20 times higher that our data. 
On the other hand, Juillard et al., 1978, found $0.1 \mathrm{ppm}$ of dieldrin in liver of two individuals collected in Switzerland. We have obtained dieldrin only in 6 of the 23 analyzed samples, and at lower concentrations than the cited authors.

This study shows that contamination of barn owls by organochlorine pesticides is low in Leon, Spain.

\section{REFERENCES}

Ahmad N (1979) Cleanup of biological samples for determining $p, p^{\prime}-D D T$ and its metabolites. J Assn offic Anal Chem 62:1150$-1154$

Joiris C, Lauwereys M, Vercruysse A (1977) PCB and

organochlorine pesticides residues in eggs of birds of prey

collected in Belgium in 1972, 1973, 1974. Le Gerfaut 67:447-458.

Juillard M, Praz JC, Etournaud A, Beaud P (1978) Donnés sur la contamination des rapaces de Suisse romande et de leurs œufs par les biocides organochlorés, les PCB et les métaux lourds. Nos Oiseaux 34:189-206

Peakall DB, Kemp AC (1980) Organochlorine levels in owls in Canada and South Africa. Ostrich 51:186

Richardson A, Robinson J, Crabtree AN, Baldwin MK (1971) Residues in fish, wildlife and stuaries. Pestic Monitor $J$ 4:169-176

Sierra M, Gallego A, Terán MT, Santiago D (1984) Niveles de resíduos de $\alpha-H C H, p, p^{\prime}-D D E Y$ p, $p^{\prime}-D D T$ en tejidos de ratonero común (Buteo buteo, L.) capturados en la provincia de León. Revista de Toxicología 1:67-73

Received February 10, 1986; accepted July 25, 1986 